\title{
$\beta$-Amyloid Regulation of Presynaptic Nicotinic Receptors in Rat Hippocampus and Neocortex
}

\author{
John J. Dougherty, Jianlin Wu, and Robert A. Nichols \\ Department of Pharmacology and Physiology, Drexel University College of Medicine, Philadelphia, Pennsylvania 19102
}

\begin{abstract}
Alteration by $\beta$-amyloid $(\mathrm{A} \beta)$ of signaling via nicotinic acetylcholine receptors (nAChRs) has been implicated in the early stages of Alzheimer's disease. nAChRs function both post- and presynaptically in the nervous system; however, little is known about the functional consequence of the interaction of $A \beta$ with these receptors, particularly those on presynaptic nerve terminals. In view of the strong correlation between loss of synaptic terminals and dementia, together with the reduction in nAChRs in Alzheimer's disease, the possibility exists that presynaptic nAChRs may be targets for $\mathrm{A} \beta$. To explore this possibility, we assessed the effect of $\mathrm{A} \beta$ peptides on nicotine-evoked changes in presynaptic $\mathrm{Ca}^{2+}$ level via confocal imaging of isolated presynaptic nerve endings from rat hippocampus and neocortex. $\mathrm{A} \beta_{1-42}$ appeared to inhibit presynaptic nAChR activation by nicotine. Surprisingly, picomolar $\mathrm{A} \beta_{1-42}$ was found to directly evoke sustained increases in presynaptic $\mathrm{Ca}^{2+}$ via nAChRs, revealing that the apparent inhibitory action of $\mathrm{A} \beta_{1-42}$ was the result of an occlusion of nicotine to further stimulate the receptors. The direct effect of $\mathrm{A} \beta$ was found to be sensitive to $\alpha$-bungarotoxin, mecamylamine, and dihydro- $\beta$-erythroidine, indicating involvement of $\alpha$-containing $\mathrm{nAChRs}$ and non- $\alpha$-containing $\mathrm{nAChRs.} \mathrm{Prior}$ depolarization strongly attenuated subsequent $\mathrm{A} \beta$-evoked responses in a manner dependent on the amplitude of the initial presynaptic $\mathrm{Ca}^{2+}$ increase, suggesting that nerve activity or $\mathrm{Ca}^{2+}$ channel density may control the impact of $\mathrm{A} \beta$ on presynaptic nerve terminal function. Together, these results suggest that the sustained increases in presynaptic $\mathrm{Ca}^{2+}$ evoked by $\mathrm{A} \beta$ may underlie disruptions in neuronal signaling via nAChRs in the early stages of Alzheimer's disease.
\end{abstract}

Key words: nicotinic receptor; amyloid; presynaptic; hippocampus; calcium imaging; Alzheimer's disease

\section{Introduction}

One prominent feature of Alzheimer's disease is the presence of neuritic plaques containing $\beta$-amyloid $(\mathrm{A} \beta)$ peptides. $\mathrm{A} \beta$ peptides (39-43 amino acids in length) are generated by proteolytic cleavage of the $\mathrm{A} \beta$ precursor protein, a transmembrane glycoprotein present in multiple isoforms (Selkoe, 1998; Walter et al., 2001). The dominant peptide fragment present within the neuritic plaques, as insoluble fibrils, is the 42-residue species $\mathrm{A} \beta_{1-42}$ (Iwatsubo et al., 1994; Gravina et al., 1995; Selkoe, 1998). The A $\beta$ fibrils most likely result from self-aggregation of the $\mathrm{A} \beta_{1-42}$ (Teplow, 1998; Huang et al., 2000). There is, however, only a weak correlation between fibrillar $\mathrm{A} \beta$ content and cognitive dysfunction (Lue et al., 1999; McLean et al., 1999). In contrast, the severity of dementia does correlate with the degree of loss of presynaptic terminals (Terry et al., 1991; Sze et al., 1997) as well as with the total load of soluble A $\beta$ (Lue et al., 1999; McLean et al., 1999). Moreover, transgenic strains exist (e.g., Tg2576) wherein $\mathrm{A} \beta$ levels are elevated without plaque formation or nerve cell loss, yet learning and memory deficits are evident (Irizarry et al., 1997; Kotilinek et al., 2002; Westerman et al., 2002). Consequently, it

Received Feb. 13, 2003; revised May 27, 2003; accepted May 30, 2003.

This work was supported in part by the Smokeless Tobacco Research Council. We thank Drs. Michael White and Robert Moreland for helpful comments on this manuscript. We thank Brett Brown for technical assistance.

Correspondence should be addressed to Dr. Robert A. Nichols, Department of Pharmacology and Physiology, Drexel University College of Medicine (formerly MCP Hahnemann University), 245 North 15th Street, Philadelphia, PA 19102. E-mail: robert.nichols@drexel.edu.

Copyright $\odot 2003$ Society for Neuroscience $\quad$ 0270-6474/03/236740-08\$15.00/0 has been hypothesized that $\mathrm{A} \beta$ may be largely acting in a soluble form (dimers and/or small oligomers, also referred to as ADDLs) (Garzon-Rodriguez et al., 1997) to disrupt neuronal signaling (Lambert et al., 1998; Klein et al., 2001), particularly at an early stage in Alzheimer's disease, with nicotinic acetylcholine receptors (nAChRs) as a major target (Auld et al., 1998). Other possible targets have been suggested, such as microglial scavenger receptors (El Khoury et al., 1998) and the receptor for advanced glycation end products (Lue et al., 2001).

Evidence for a strong interaction between $\mathrm{A} \beta$ and specific nAChRs, particularly $\alpha 7$ subunit-containing nAChRs, has accumulated (Dineley et al., 2001; Liu et al., 2001; Pettit et al., 2001; Wang et al., 2000a,b). Studies examining binding of $A \beta_{1-42}$ to $n A C h R s$ expressed on clonal cell lines indicated that $\mathrm{A} \beta$ has a picomolar affinity for $\alpha 7$-containing nAChRs (Wang et al., 2000a). In both rat hippocampal slices (Pettit et al., 2001) and cultured neurons (Liu et al., 2001), nanomolar $A \beta$ was shown to inhibit nicotine-evoked currents, including $\alpha 7$-AChRs and non- $\alpha 7$-AChRs, in a reversible, apparently noncompetitive manner. In addition, acute treatment with $\mathrm{A} \beta$ was found to activate the MAP kinase cascade in mouse hippocampal slices via $\alpha 7$-nAChRs, whereas chronically elevated $\mathrm{A} \beta$ in a mouse model of Alzheimer's disease led to downregulation of MAP kinase with concomitant upregulation of $\alpha 7$-nAChRs in aged animals (Dineley et al., 2001). These latter data suggest that $\mathrm{A} \beta$ may first activate and then inhibit nAChRs, although no direct activation by $A \beta$ of $n A C h R s$ was noted in any of the aforementioned reports using primary tissue. 

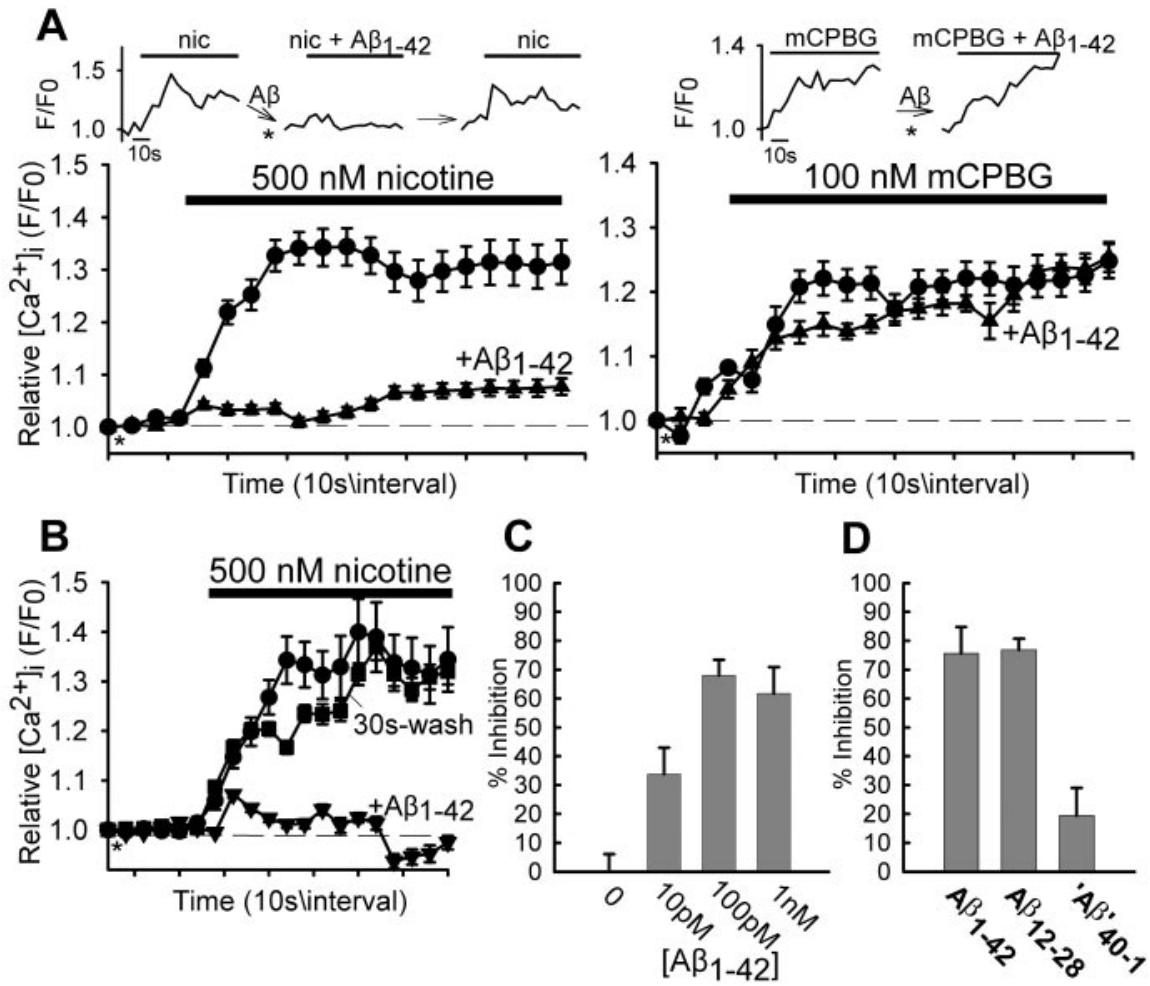

Figure 1. Inhibitory effect of $A \beta$ on nicotine-evoked increases in $\mathrm{Ca}^{2+}$ level in individual isolated hippocampal nerve endings. $A$, Successive stimulation with $500 \mathrm{~nm}$ nicotine (left) or $100 \mathrm{~nm}$ of the $5-\mathrm{HT}_{3}$ agonist $m$-chlorophenyl biguanide (mCPBG; right) in the absence or presence of $100 \mathrm{~nm} A \beta_{1-42}$ during an intervening 10-min wash period and the second stimulation. Top, Representative successive $\mathrm{Ca}^{2+}$ responses in individual synaptosomes. Bottom, Averaged responses expressed as means \pm SEM before and after incubation of $A \beta_{1-42}$. Left graph, $n=45$; Right graph, $n=15$. Reversibility $(B)$, concentration dependence $(C)$, and peptide specificity $(D)$ of the inhibitory effect of $100 \mathrm{~nm} \mathrm{~A} \beta_{1-42}$ were also examined. In $D$, peptides were present at $100 \mathrm{~nm}$. Note that for $A, B, \mathrm{Ca}^{2+}$ responses to the second stimulation were renormalized $\left({ }^{*}\right)$, although a maintained $\mathrm{Ca}^{2+}$ increase occurred with $A \beta$ (Fig. 3). In $C, D$, data are expressed as percentage of control plateau values (\% inhibition). $B, n=13 ; C: 0 \mathrm{pm}, n=26 ; 10$ $\mathrm{pm}, n=8 ; 100 \mathrm{pm}, n=5 ; 1 \mathrm{~nm}, n=8 ; D: A \beta_{1-42}, n=73 ; \mathrm{A} \beta_{12-28}, n=15 ;{ }^{\prime} \mathrm{A} \beta^{\prime}{ }_{40-1}, n=6$.

To determine the consequence of $\mathrm{A} \beta$ action on presynaptic nicotinic receptors on nerve terminal signaling, we investigated the effects of $\mathrm{A} \beta$ peptides on nicotine-induced $\mathrm{Ca}^{2+}$ responses in individual isolated nerve terminals from rat hippocampus and neocortex.

\section{Materials and Methods}

Materials. Synthetic A $\beta$ peptides were purchased from BACHEM (King of Prussia, PA). For all experiments, $\mathrm{A} \beta$ peptides were suspended in physiological saline at $100-1000 \times$ stock concentration, thoroughly bath sonicated, and then immediately diluted for use. Under these conditions, the final solutions (picomolar-nanomolar peptide) remain clear, with no visible particles when viewed by phase-contrast microscopy (Lorenzo and Yankner, 1994), for the course of an experiment (15-30 min). Fluo-3 and fluo- 4 were obtained from Molecular Probes, Inc. (Eugene, OR) and are kept as $1 \mathrm{~mm}$ stock solutions in DMSO at $-20^{\circ} \mathrm{C}$. Cell-Tak was purchased from Collaborative Biomedical Products (Bedford, MA). Nicotine, $m$-chlorophenyl biguanide, $\alpha$-bungarotoxin, mecamylamine, and dihydro- $\beta$-erythroidine were purchased from Sigma (St. Louis, MO). Conotoxins and agatoxin-TK were purchased from Alomone Labs (Jerusalem, Israel). All drugs and toxins were suspended in physiological saline just before use.

Synaptosome preparation. Hippocampi, striata, or cortices were dissected out of brains from adult male Sprague Dawley rats (Taconic Farms, Germantown, NY) and immediately placed in ice-cold $0.32 \mathrm{~m}$ sucrose, following a protocol approved by the Drexel University College of Medicine (formerly MCP Hahnemann University) Institutional Animal Care and Use Committeee. Tissue was then homogenized in $0.32 \mathrm{M}$ sucrose using a glass Teflon tissue grinder. Synaptosomes were isolated according to the method described by Dunkley et al. (1986). The preparations were washed into oxygenated HEPES-buffered saline [HBS; composition (in $\mathrm{mm}$ ): $142 \mathrm{NaCl}, 2.4 \mathrm{KCl}, 1.2$ $\mathrm{K}_{2} \mathrm{PO}_{4}, 1 \mathrm{MgCl}_{2}, 5$ D-glucose, and 10 HEPES, $\mathrm{pH}$ 7.4]. This procedure yields synaptosomes, $\sim 90 \%$ of which have shown to be intact and functional, based on the stability and consistency of $\mathrm{Ca}^{2+}$ responses of dye-loaded synaptosomes to multiple rounds of stimulation as gauged using confocal imaging (Nayak et al., 2000, 2001).

Calcium imaging. Synaptosomes were loaded with fluorescent $\mathrm{Ca}^{2+}$ indicator dye (fluo-3 or fluo-4) at $5 \mu \mathrm{M}$ by incubating with the acetoxymethyl ester derivative in HBS for 30-45 $\min$ at $37^{\circ} \mathrm{C}$. Dye-loaded preparations were washed in $\mathrm{HBS}$ containing $1 \mathrm{~mm} \mathrm{CaCl}_{2}$ and then plated onto Cell-Tak-coated coverslips. Relative changes in internal $\mathrm{Ca}^{2+}$ in individual synaptosomes were assessed using confocal imaging (Rondé and Nichols, 1998; Nayak et al., 2001) via a Nikon PCM 2000 laser-scanning confocal imaging system connected to a Nikon Diaphot 300 microscope. In brief, the preparations on coverslips were mounted in a rapidexchange Warner (36 $\mu$ l volume) perfusion system attached to the microscope and subjected to perfusion with $\mathrm{HBS}$ containing $\mathrm{Ca}^{2+}$ at $3-5$ $\mathrm{ml} / \mathrm{min}$. Imaging was commenced, and after obtaining a baseline series of five images, stimulatory agents were applied by rapid switching between manifolds on the perfusion system. Complete exchange of the perfusion chamber took place in $<1 \mathrm{sec}$. Images were typically collected at 4-sec intervals, although in several experiments 15 -sec intervals were used. A given experiment corresponded to a series of images captured from a single preparation. The fluorescent intensities associated with a given structure, determined from digitized images using OPTIMAS image analysis software (Optimas Co., Seattle, WA), were expressed as normalized values $\left(\mathrm{F} / \mathrm{F}_{0}\right.$; where $\mathrm{F}_{0}=$ fluorescence intensity at $\left.\mathrm{t}_{0}\right)$. All time series were corrected for photobleaching.

Statistics. Data sets were compared using matched Student's $t$ tests. Significance was indicated when $p$ was minimally $<0.05$.

\section{Results}

Nicotine induces robust increases in $\mathrm{Ca}^{2+}$ level in a subpopulation $(10-25 \%)$ of isolated nerve terminals (synaptosomes), which slowly decay (several minutes) depending on concentration and receptor subtype (Nayak et al., 2001). The nicotineinduced $\mathrm{Ca}^{2+}$ responses in striatal synaptosomes were found to be effectively independent of voltage-gated $\mathrm{Ca}^{2+}$ channels, indicating that the sustained changes in internal $\mathrm{Ca}^{2+}$ likely parallel, although certainly with some delay, the influx of $\mathrm{Ca}^{2+}$ via the nicotinic receptor channel. Nicotine-induced $\mathrm{Ca}^{2+}$ responses in hippocampal or cortical synaptosomes, in contrast, display significant dependence on voltage-gated $\mathrm{Ca}^{2+}$ channels, as gauged by sensitivity to $\mathrm{Ca}^{2+}$ channel toxins wherein responses were inhibited to $30-40 \%$ of controls, indicating a strong depolarizing component to the responses in the nerve terminals in these brain regions. Sustained elevation in internal $\mathrm{Ca}^{2+}$ seems to be a common feature underlying responses in nerve terminals to activation of presynaptic nicotinic receptors (McGehee et al., 1995; Gray et al., 1996; Coggan et al., 1997; Léna and Changeux, 1997; Mansvelder and McGehee, 2000; Kiyosawa et al., 2001; Díaz- 
Hernández et al., 2002), as well as the closely related 5- $\mathrm{HT}_{3}$ serotonin receptors when expressed on presynaptic nerve endings (Rondé and Nichols, 1998, 2001).

Treatment with $\mathrm{A} \beta_{1-42}$ appeared to strongly inhibit nicotineinduced $\mathrm{Ca}^{2+}$ responses in individual hippocampal synaptosomes in a readily reversible manner (Fig. $1 A$, left), with the nicotine-induced $\mathrm{Ca}^{2+}$ responses recovering to a significant degree as soon as $30 \mathrm{sec}$ after washing out the $\mathrm{A} \beta_{1-42}$ (Fig. $1 \mathrm{~B}$ ). The action of $\mathrm{A} \beta_{1-42}$ on nicotinic receptors present on the presynaptic terminals appears to be specific, because it had no significant effect on presynaptic $5-\mathrm{HT}_{3}$ serotonin receptor-induced $\mathrm{Ca}^{2+}$ responses in the same synaptosomes (Fig. $1 A$, right), as assessed using the highly selective $5-\mathrm{HT}_{3}$ receptor agonist $m$-chlorophenyl biguanide. The latter conclusion was made based on the finding that $5-\mathrm{HT}_{3}$ serotonin receptors colocalize with nicotinic receptors at presynaptic sites (Nayak et al., 2000). The lack of significant effect of $\mathrm{A} \beta_{1-42}$ on $5-\mathrm{HT}_{3}$ receptors is also consistent with previous reports (Wang et al., 2000a; Liu et al., 2001). In addition, $\mathrm{A} \beta_{1-42}$ has been shown to have no effect on glutamate receptors in a hippocampal preparation (Pettit et al., 2001). The inhibitory effect of $A \beta_{1-42}$ was concentration dependent, with low nanomolar levels producing near complete blockade of the nicotineinduced $\mathrm{Ca}^{2+}$ responses, whereas significant inhibition was evident down into the picomolar range $\left(\mathrm{IC}_{50}, \sim 10\right.$ pM; Fig. $1 C$ ). Finally, a control peptide having a reversed sequence (40-1; 'A $\beta^{\prime}{ }_{40-1}$ used at $100 \mathrm{~nm}$ ) from that of $\mathrm{A} \beta_{1-42}$ had no significant effect on nicotine-induced $\mathrm{Ca}^{2+}$ responses in the hippocampal synaptosomes (Fig. $1 D$ ). In contrast, $100 \mathrm{nM} \mathrm{A} \beta_{12-28}$ was nearly as effective as $100 \mathrm{nM} \mathrm{A} \beta_{1-42}$ in inhibiting the nicotine-induced responses (Fig. $1 D$ ). $\mathrm{A} \beta_{12-28}$ was previously shown to interact strongly with $\alpha 7$-nAChRs (Wang et al., 2000b), suggesting that it may contain the nicotinic receptor-binding motif of the $\mathrm{A} \beta$ peptides. $\mathrm{A} \beta_{12-28}$ was also shown to block nicotine-induced currents in hippocampal neurons, as, if not more, effectively as $\mathrm{A} \beta_{1-42}$ (Pettit et al., 2001). These results indicate that presynaptic nicotinic receptors are selectively inhibited by soluble $A \beta$. However, because each $\mathrm{Ca}^{2+}$ response is normalized to baseline, the question arises as to whether $\mathrm{A} \beta$ has a direct effect on presynaptic $\mathrm{Ca}^{2+}$ levels, resulting in an occlusion of the nicotine-induced $\mathrm{Ca}^{2+}$ responses, in contrast to direct inhibition of the presynaptic nicotinic receptor. As described later, the inhibitory effect of $\mathrm{A} \beta$ was indeed because of an occlusion, i.e., full activation of the nAChRs, preventing further activation by nicotine.

Nicotine-induced $\mathrm{Ca}^{2+}$ responses in a subset of hippocampal synaptosomes ( $12 \pm 6 \% \mathrm{SD}$ ) seem to involve both $\alpha 7$-containing nAChRs and non- $\alpha 7$-containing nAChRs (Fig. $2 A$ ), as gauged by sensitivity of the responses to various nicotinic receptor antagonists ( $\alpha 7, \alpha$-bungarotoxin; non- $\alpha 7$, dihydro- $\beta$-erythroidine or mecamylamine), consistent with studies of nicotine-induced neurotransmitter release (Clarke and Reuben, 1996; Gray et al., 1996; Radcliffe et al., 1999; Fabian-Fine et al., 2001; Kulak et al., 2001). The profiles of sensitivity of presynaptic nicotine-induced $\mathrm{Ca}^{2+}$ responses were similar between hippocampal and cortical synaptosomes (data not shown). Interestingly, the apparent inhibitory effect of $A \beta_{1-42}$ was more pronounced with hippocampal and cortical synaptosomes as compared with striatal synaptosomes (Fig. $2 B$ ). Although $\mathrm{A} \beta_{1-42}$ has been shown to inhibit non- $\alpha 7$-containing nAChRs (Pettit et al., 2001), it displays the highest affinity for $\alpha 7$-containing nAChRs (Wang et al., 2000b), and $\alpha 7$-containing nAChRs appear to be a minor presence, at best, on striatal nerve terminals (Nayak et al., 2000; cf. Marchi et al., 2002), perhaps explaining the much smaller effect of $\mathrm{A} \beta_{1-42}$ on striatal synaptosomes, particularly when used at 100 pM. Evi-

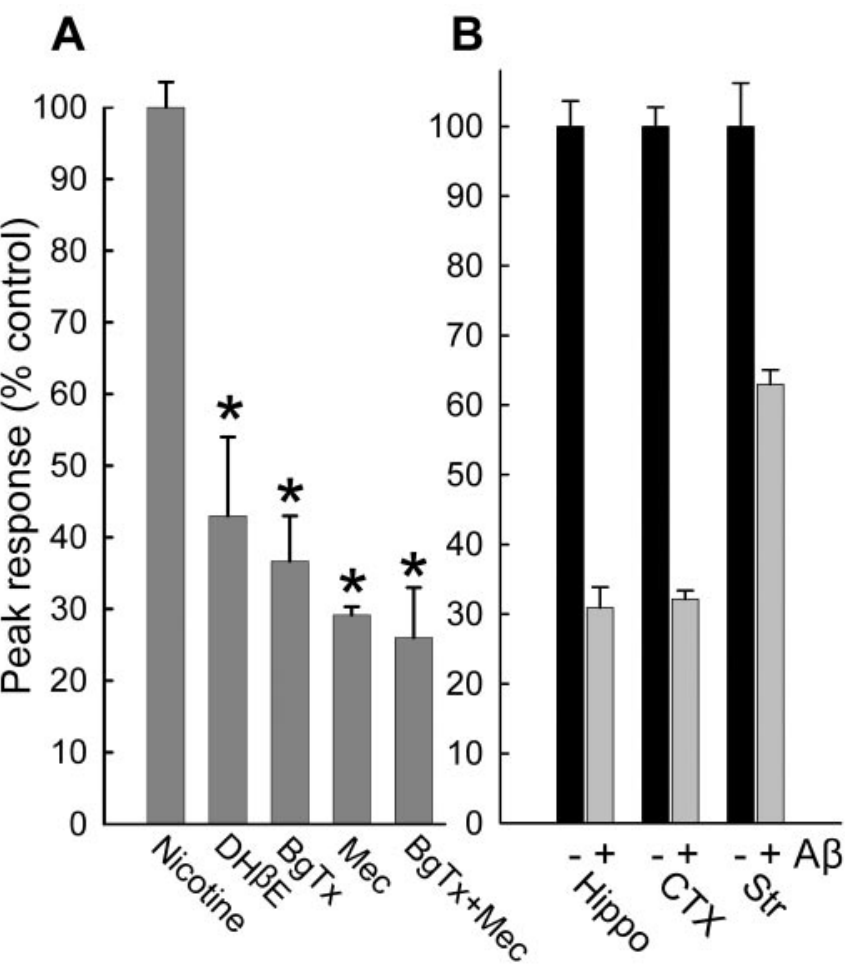

Figure 2. Sensitivity of nicotine-evoked presynaptic $\mathrm{Ca}^{2+}$ increases to various nicotinic antagonists and to $A \beta$ for preparations from various regions of the brain. $A$, Average maximal $\mathrm{Ca}^{2+}$ responses to $500 \mathrm{~nm}$ nicotine in hippocampal synaptosomes in the absence $(n=34)$ or presence of $5 \mu$ m dihydro- $\beta$-erythroidine (DH $\beta \mathrm{E} ; n=26), 500 \mathrm{~nm} \alpha$-bungarotoxin (BgTx; $n=$ 9), $10 \mu \mathrm{m}$ mecamylamine (Mec; $n=18)$, or BgTx plus $\operatorname{Mec}(n=11)$ during the second stimulation, using the successive stimulation protocol described in the legend to Figure 1. $B$, Inhibitory effects of $100 \mathrm{~nm} \mathrm{~A} \beta_{1-42}$ on nicotine-evoked $\mathrm{Ca}^{2+}$ responses in synaptosomes from hippocampus (Hippo; $n=17)$, cortex (CTX; $n=13)$, or striatum (Str; $n=10)$. Qualitatively similar results were obtained using $100 \mathrm{pm} \mathrm{A} \beta_{1-42} \cdot{ }^{*} p<0.05$; $t$ test with paired control.

dence for involvement of $\alpha 7$-containing nAChRs on hippocampal synaptosomes is indicated by $\alpha$-bungarotoxin sensitivity of direct effects of $\mathrm{A} \beta_{1-42}$ to increase synaptosomal $\mathrm{Ca}^{2+}$ (Fig. 5).

$\mathrm{A} \beta_{1-42}$ was found to induce directly substantial increases in $\mathrm{Ca}^{2+}$ level (Fig. 3) in a subset of hippocampal synaptosomes $(17 \pm 10 \% \mathrm{SD})$, with sustained elevation in $\mathrm{Ca}^{2+}$ level evident for over 10 min of incubation (Fig. $3 A$ ). A $\beta_{1-42}$-induced synaptosomal $\mathrm{Ca}^{2+}$ responses were comparable in number and average magnitude to those evoked by nicotine stimulation. The direct effect of $\mathrm{A} \beta_{1-42}$ was concentration dependent, with measurable responses in the low picomolar range (Fig. $3 C$ ). Similar findings were obtained using cortical synaptosomes; however, the increases in $\mathrm{Ca}^{2+}$ level in response to $100 \mathrm{pM} \mathrm{A} \beta_{1-42}\left(\mathrm{~F} / \mathrm{F}_{0}, 1.13 \pm\right.$ $0.03 \mathrm{SEM} ; n=23$ ) were substantially lower than those seen in response to $100 \mathrm{nM} \mathrm{A} \beta_{1-42}\left(\mathrm{~F} / \mathrm{F}_{0}, 1.45 \pm 0.03 \mathrm{SEM} ; n=30\right)$, in contrast to what was observed for $\mathrm{A} \beta_{1-42}$-evoked responses in hippocampal synaptosomes at these same concentrations, indicating a significantly lower potency of $\mathrm{A} \beta$ for cortical presynaptic terminals. These direct effects of $A \beta$ were unaltered by filtration of the $\mathrm{A} \beta_{1-42}$-containing HBS perfusion solution (Fig. $3 E$ ), indicating that the $\mathrm{A} \beta$ was not acting via an aggregated form. $\mathrm{A} \beta_{12-28}$ was also able to induce directly increases in synaptosomal $\mathrm{Ca}^{2+}$ (Fig. 3B). Interestingly, synaptosomal $\mathrm{Ca}^{2+}$ responses to picomolar $\mathrm{A} \beta_{1-42}$ were dependent on external $\mathrm{Ca}^{2+}$, whereas they were only partially dependent on external $\mathrm{Ca}^{2+}$ for concentrations of $\mathrm{A} \beta_{1-42}$ in the high nanomolar to micromolar range (Fig. $4 A)$. However, $\mathrm{Zn}^{2+}(50 \mu \mathrm{M})$, known to block alleged $\mathrm{A} \beta$ chan- 


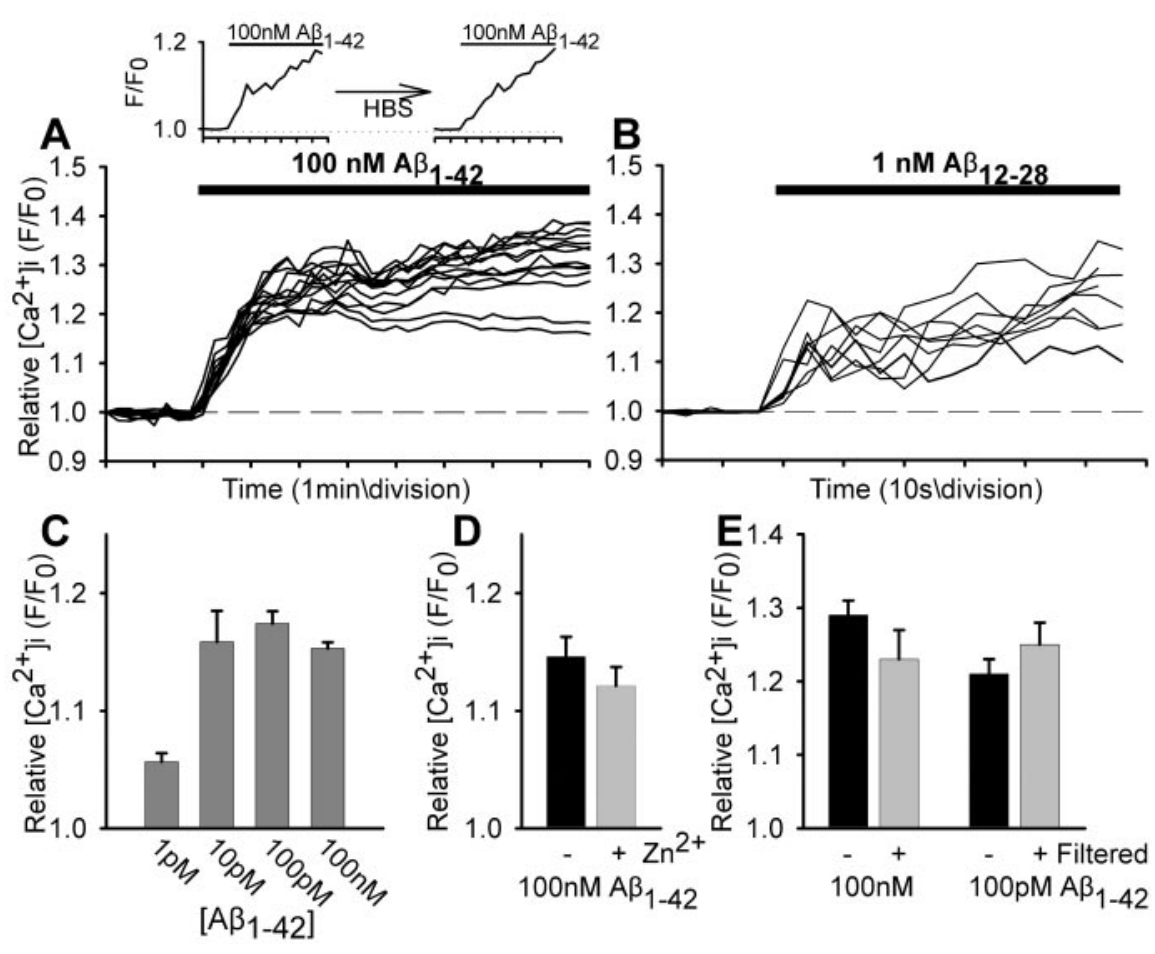

Figure 3. $A \beta$-evoked $\mathrm{Ca}^{2+}$ increases in individual hippocampal nerve endings. Composites of $\mathrm{Ca}^{2+}$ responses in individual synaptosomes to $A \beta_{1-42}(A)$ and $A \beta_{12-28}(B)$ over an extended time course. Top, Representative initial phases of successive $\mathrm{Ca}^{2+}$ responses in an individual synaptosome to $100 \mathrm{~nm} \mathrm{~A} \beta_{1-42}$. Data sampling were 4-sec intervals. $C$, Concentration dependence: $1 \mathrm{pm}, n=26 ; 10 \mathrm{pm}, n=20 ; 100 \mathrm{pm}, n=116 ; 100 \mathrm{~nm}, n=175 . D$, Insensitivity to prior treatment with $50 \mu \mathrm{m} Z \mathrm{nCl}_{2}(n=$ 15). $E$, Average maximal $\mathrm{Ca}^{2+}$ responses to $100 \mathrm{~nm} \mathrm{~A} \beta_{1-42}(n=11)$ or $100 \mathrm{pm} \mathrm{A} \beta_{1-42}(n=14)$ before or after filtration of the A $\beta$ solutions through $0.2 \mu \mathrm{m}$ filters.

nels that form at relatively high (micromolar) concentrations of $\mathrm{A} \beta_{1-42}$ (Lin et al., 2001), had no effect on synaptosomal $\mathrm{Ca}^{2+}$ responses to $\mathrm{A} \beta_{1-42}$ at any concentration (Fig. $3 D$ ). Moreover, the stimulatory effect of $\mathrm{A} \beta_{1-42}$ was partially dependent on voltage-gated $\mathrm{Ca}^{2+}$ channels at $100 \mathrm{pm}$ but not at $100 \mathrm{~nm}$ (Fig. $4 B)$, as gauged by the insensitivity of the $\mathrm{A} \beta_{1-42}$-induced $\mathrm{Ca}^{2+}$ responses to inhibition by a mixture of $\mathrm{Ca}^{2+}$ channel blockers (agatoxin-TK, o-conotoxin MVIIC, o-conotoxin GVIA) shown previously to block $\mathrm{K}^{+}$-induced synaptosomal $\mathrm{Ca}^{2+}$ responses (Rondé and Nichols 1998). Similar results were obtained when $\mathrm{Ca}^{2+}$ channels were blocked with micromolar $\mathrm{Cd}^{2+}$ plus $\mathrm{Co}^{2+}$ (data not shown). The relative sensitivity of nicotine-induced $\mathrm{Ca}^{2+}$ responses to $\mathrm{Ca}^{2+}$ blockers was similar to that seen for 100 pм А $\beta_{1-42}$-induced responses (data not shown). Finally, the direct effect of $\mathrm{A} \beta_{1-42}$ was sensitive to $\alpha$-bungarotoxin (Fig. $5 A$ ), the open-channel blocker mecamylamine (Fig. $5 B$ ), and dihydro$\beta$-erythroidine (Fig. $5 D$ ), to extents comparable with the inhibitory effects of these nicotinic antagonists on nicotine-induced $\mathrm{Ca}^{2+}$ responses (compare Fig. 2), indicating a significant involvement of $\alpha 7$-containing nAChRs and non- $\alpha 7$-containing nAChRs. Interestingly, the effect of $\alpha$-bungarotoxin was more pronounced when $\mathrm{A} \beta_{1-42}$ was used at $100 \mathrm{pm}$, whereas the effect of dihydro- $\beta$-erythroidine was more pronounced when $\mathrm{A} \beta_{1-42}$ was used at $100 \mathrm{~nm}$. Combining $\alpha$-bungarotoxin with mecamylamine led to an inhibition profile similar to that of $\alpha$-bungarotoxin alone (Fig. 5C). These results indicate that soluble $\mathrm{A} \beta$ at picomolar concentration directly activates presynaptic nAChRs predominantly of the $\alpha 7$-containing subtype to increase nerve terminal $\mathrm{Ca}^{2+}$ in a manner dependent on entry of $\mathrm{Ca}^{2+}$ through both the nAChR receptor channel and voltage-gated
$\mathrm{Ca}^{2+}$ channels, whereas soluble $\mathrm{A} \beta$ at nanomolar concentration directly activates presynaptic nAChRs predominantly of the non- $\alpha 7$-containing subtype to increase nerve terminal $\mathrm{Ca}^{2+}$ largely via the $\mathrm{nAChR}$ receptor channel.

Because the apparent inhibitory effect of $\mathrm{A} \beta_{1-42}$ on nicotine-induced responses (Fig. 1) was observed under conditions in which each response was necessarily normalized to the initial baseline, owing to uncertainty over baseline values after extended treatment periods without imaging, sequential addition of $\mathrm{A} \beta$ and nicotine was performed while imaging. The addition of $500 \mathrm{~nm}$ nicotine just after the initial application of $\mathrm{A} \beta_{1-42}$ to hippocampal synaptosomes resulted in no further increase in $\mathrm{Ca}^{2+}$ level over that obtained in response to $\mathrm{A} \beta_{1-42}$ alone (Fig. $6 A$ ), indicating that $\mathrm{A} \beta_{1-42}$ strongly attenuates $\mathrm{Ca}^{2+}$ responses to nanomolar concentrations of nicotine in these nerve endings. In contrast, increasing nicotine to the micromolar range revealed nicotine-induced $\mathrm{Ca}^{2+}$ responses on top of the initial $\mathrm{A} \beta_{1-42^{-}}$ induced responses. The control reverse peptide, 'A $\beta^{\prime}{ }_{40-1}$, caused no significant change in the synaptosomal $\mathrm{Ca}^{2+}$ level and did not significantly inhibit responses to nicotine added on top of the ' $\mathrm{A} \beta^{\prime}{ }_{40-1}$ (Fig. $6 A$ ). Likewise, the addition of $\mathrm{A} \beta_{1-42}$ just after the initial application of $500 \mathrm{nM}$ nicotine had no significant effect on nicotine-induced $\mathrm{Ca}^{2+}$ responses when applied at $10 \mathrm{pm}$ to $1 \mathrm{~nm}$ on top of nicotine, but it did increase synaptosomal $\mathrm{Ca}^{2+}$ when applied at $10-100 \mathrm{~nm}$ (Fig. $6 C, D)$. In either case, in which relatively high concentrations of the second stimulatory agent were used (Fig. $3 C$ ), all synaptosomes responding to $\mathrm{A} \beta$ also responded to nicotine. Taken together, these results indicate that activation of presynaptic nicotinic receptors by picomolar $A \beta_{1-42}$ occludes the action of nicotine on the same receptors when applied at typical maximal concentration $(500 \mathrm{~nm})$ and vice versa. That the occlusion was not the result of a saturating $\mathrm{Ca}^{2+}$ response or dye saturation is evident in the ability of elevated concentrations to elicit responses (Fig. $6 B, D$ ). Thus, the apparent inhibitory effect of $\mathrm{A} \beta$ on nicotine-induced $\mathrm{Ca}^{2+}$ responses (Fig. 1) was a consequence of prior activation of the $\mathrm{nAChRs}$ by $\mathrm{A} \beta$.

Prior depolarization with elevated external $\mathrm{K}^{+}$resulted in significant attenuation of subsequent $\mathrm{A} \beta_{1-42}$-evoked $\mathrm{Ca}^{2+}$ responses (Fig. 7A) in a manner that was dependent on the amplitude of the initial $\mathrm{K}^{+}$-evoked response (Fig. $7 B$ ). Under any condition, application of $30 \mathrm{~mm}$ (or higher) $\mathrm{KCl}$ will substantially depolarize all of the synaptosomes in the preparation; however, a wide range of response amplitudes are observed (cf. Nichols and Mollard, 1996). When $\mathrm{Ca}^{2+}$ responses were first evoked with $\mathrm{A} \beta_{1-42}$ and followed by subsequent depolarization, the $\mathrm{K}^{+}$evoked $\mathrm{Ca}^{2+}$ responses were correspondingly attenuated (Fig. $7 C$ ) in a manner somewhat dependent on the amplitude of the initial $\mathrm{A} \beta_{1-42}$-evoked response (Fig. $7 D$ ). In this case, even the largest $\mathrm{K}^{+}$-evoked $\mathrm{Ca}^{2+}$ responses were substantially smaller after initial $\mathrm{A} \beta_{1-42}$ stimulation in comparison with typical $\mathrm{Ca}^{2+}$ responses evoked by $\mathrm{K}^{+}$alone (compare Fig. $7 A$ ). These results 
A

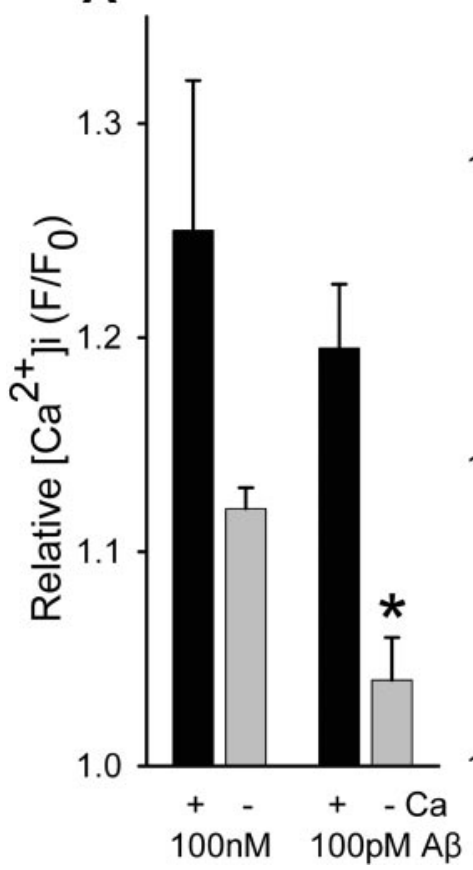

B

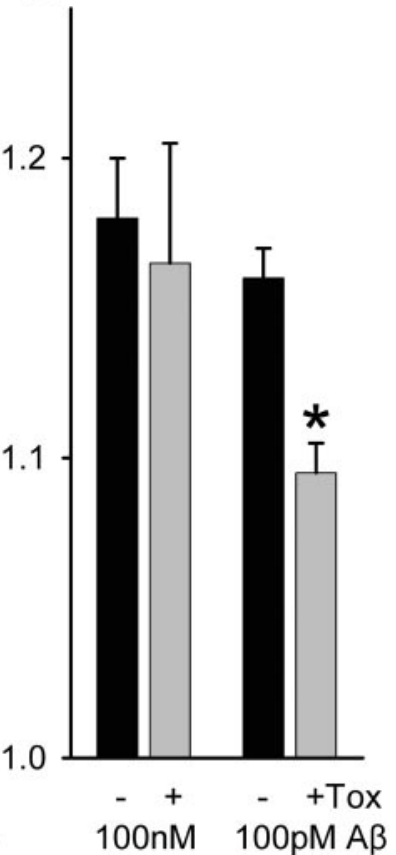

Figure 4. Dependence of $A \beta$-evoked $\mathrm{Ca}^{2+}$ increases in isolated hippocampal nerve endings on $\mathrm{Ca}^{2+}$ entry and voltage-gated $\mathrm{Ca}^{2+}$ channels. $A$, Average maximal responses $\mathrm{Ca}^{2+}$ responses to $100 \mathrm{~nm}(n=16)$ or $100 \mathrm{pm}(n=7) \mathrm{A} \beta_{1-42}$ in the absence or presence of $1 \mathrm{~mm}$ external $\mathrm{Ca}^{2+}$. $B$, Average maximal $\mathrm{Ca}^{2+}$ responses to $100 \mathrm{~nm} \mathrm{~A} \beta_{1-42}(n=22)$ or $100 \mathrm{pm}$ $A \beta_{1-42}(n=17)$ in the absence or presence of a mixture of voltage-gated $\mathrm{Ca}^{2+}$ channel blockers (toxins: 200 nм agatoxin TK; 500 nm conotoxin GVIA; 500 nm conotoxin MVIIC), which have previously been shown to block completely $\mathrm{K}^{+}$depolarization-induced synaptosomal $\mathrm{Ca}^{2+}$ responses (Rondé and Nichols, 1998). ${ }^{*} p<0.05 ; t$ test with paired control.

suggest that the effect of nerve activity on presynaptic responses to $\mathrm{A} \beta$ is strictly dependent on the extent of the increase in $\mathrm{Ca}^{2+}$ level in response to presynaptic depolarization. In contrast, the presence of $\mathrm{A} \beta$ can attenuate presynaptic $\mathrm{Ca}^{2+}$ increases in response to nerve activity. To some degree, these effects may have resulted from prior activation of voltage-gated $\mathrm{Ca}^{2+}$ channels by either $\mathrm{K}^{+}$depolarization or $\mathrm{A} \beta$-induced depolarization via nAChRs, with the contribution of voltage-gated $\mathrm{Ca}^{2+}$ channels to the evoked $\mathrm{Ca}^{2+}$ signals varying widely across synaptosomes (Nichols and Mollard, 1996).

\section{Discussion}

$\mathrm{A} \beta$ accumulates in plaques near dystrophic neurites and nerve endings (Brendza et al., 2003). Moreover, synaptic loss is strongly correlated with severity of dementia (Terry et al., 1991; Sze et al., 1997). As yet, effects of $A \beta$ on the presynaptic nerve terminal have not been defined clearly. The present study undertook to explore the possibility that soluble $\mathrm{A} \beta$ peptide may modulate presynaptic $\mathrm{Ca}^{2+}$ levels, evaluating first effects on nicotineinduced responses, as an extension of previous work demonstrating an inhibitory interaction between $\mathrm{A} \beta$ and $\mathrm{nAChRs}$, and later direct effects of $\mathrm{A} \beta$ itself. The observed sustained increases in presynaptic $\mathrm{Ca}^{2+}$ in response to soluble $\mathrm{A} \beta_{1-42}$ raise the question as to whether such an effect would ultimately be toxic. Interestingly, prior depolarization attenuated the effect of $\mathrm{A} \beta$, indicating that the degree of nerve activity and/or relative density of voltagegated $\mathrm{Ca}^{2+}$ channels on the nerve endings may also play a role in modulating the action of soluble $\mathrm{A} \beta$ at presynaptic sites, in particular its toxicity.
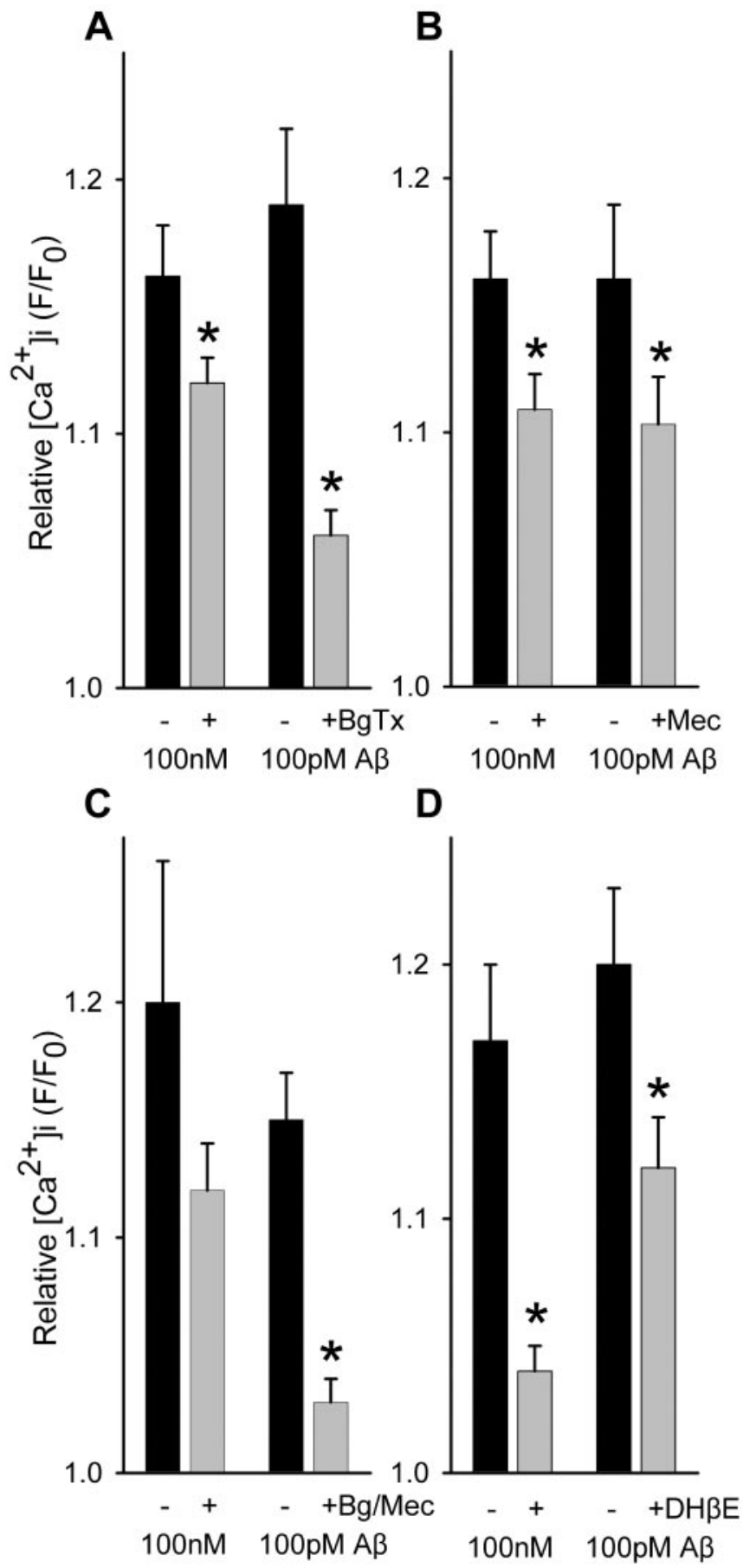

Figure 5. Sensitivity of $\mathrm{A} \beta$-evoked $\mathrm{Ca}^{2+}$ increases in isolated hippocampal nerve endings to nicotinic receptor antagonists. Average maximal responses $\mathrm{Ca}^{2+}$ responses to $A \beta_{1-42}$ in the absence or presence of $500 \mathrm{~nm} \alpha$-bungarotoxin (BgTx; $A$ ) (100 pм, $n=14 ; 100 \mathrm{~nm}, n=22), 10$ $\mu$ m mecamylamine (Mec; $B)(100 \mathrm{pm}, n=14 ; 100 \mathrm{~nm}, n=14), 500 \mathrm{~nm} \alpha$-bungarotoxin plus 10 $\mu$ m mecamylamine (Bg/Mec; $)(100 \mathrm{pm}, n=12 ; 100 \mathrm{~nm}, n=6)$, or $5 \mu$ m dihydro- $\beta$ erythroidine $(\mathrm{DH} \beta \mathrm{E} ; \mathrm{D})(100 \mathrm{pm}, n=22 ; 100 \mathrm{~nm}, n=16) .{ }^{*} p<0.05 ;$ t test with paired control.

Several previous reports have demonstrated an action of soluble A $\beta$ peptides on nicotinic receptors (Dineley et al., 2001; Liu et al., 2001; Pettit et al., 2001). In particular, $A \beta$ was found to block nicotine-stimulated increases in spontaneous neurotransmitter release from cultured hippocampal neurons (Liu et al., 2001 ), as the first clear indication of an action of $\mathrm{A} \beta$ on presynaptic nAChRs. In contrast, a recent report demonstrates a direct activation of nAChR-mediated currents in an oocyte expression 


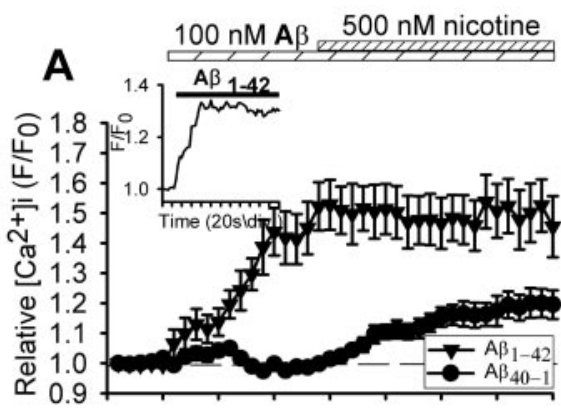

Time (20sldivision)

\section{B}

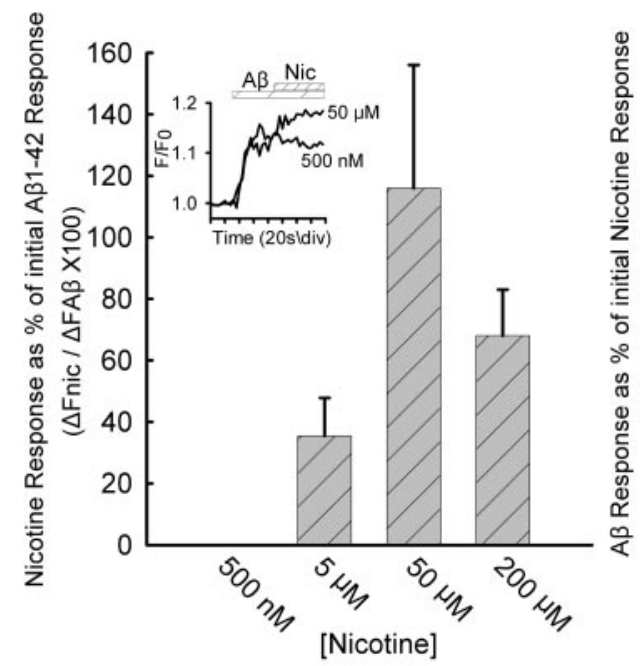

Figure 6. $\quad \mathrm{Ca}^{2+}$ responses in isolated nerve endings to $A \beta$, followed by various concentrations of nicotine $(A, B)$ compared with $\mathrm{Ca}^{2+}$ responses to nicotine, followed by various concentrations of $A \beta(C, D)$. Averaged responses in $A(n=6)$ and $C(n=13)$ are means \pm SEM. Averaged maximal responses in $B(500 \mathrm{~nm}, n=2 ; 5 \mu \mathrm{M}, n=4 ; 50 \mu \mathrm{M}, n=3 ; 200 \mu \mathrm{M}, n=5)$ and $D$ (10 pM, $n=14 ; 1 \mathrm{~nm}, n=9 ; 10 \mathrm{~nm}, n=9 ; 100 \mathrm{~nm}, n=8)$ denote the second agent as a percentage of the maximal response to the first agent. Insets, Representative responses.

system by A $\beta$ (Dineley et al., 2002). Our work confirms and extends these previous findings, showing specifically that $\mathrm{A} \beta$ can directly induce increases in presynaptic $\mathrm{Ca}^{2+}$. At picomolar $\mathrm{A} \beta$ concentration, the resultant $\mathrm{Ca}^{2+}$ responses appeared to largely involve $\alpha 7$-containing nAChRs, owing to the sensitivity of the $\mathrm{Ca}^{2+}$ responses to nicotinic antagonist $\alpha$-bungarotoxin. Interestingly, however, prior treatment with $\mathrm{A} \beta$ inhibited subsequent action of high nanomolar nicotine, a typical maximal concentration for presynaptic nAChR-evoked responses (Nayak et al., 2001 ), by occlusion. That relatively high concentrations of nicotine could overcome, to some degree, the occlusion effect of $\mathrm{A} \beta$, in the same synaptosomes, also confirms the involvement of nAChRs. Under the conditions used, these experiments cannot distinguish whether the action of $\mathrm{A} \beta$ is competitive or noncompetitive at presynaptic nAChRs, however, but do indicate significant overlap with the $\alpha$-bungarotoxin site in the case of $\alpha 7$ nAChRs. Previous results indicated that $\mathrm{A} \beta$ may be noncompetitive for acetylcholine (Liu et al., 2001), which is consistent with findings of at least two binding sites for $\mathrm{A} \beta$ on $\alpha 7$ nAChRs in ligand-binding studies (Wang et al., 2000b), and the results presented here do not exclude this possibility. Further study will be needed to determine how $\mathrm{A} \beta$ specifically interacts with presynaptic nAChRs.

Although $\alpha 7$-containing nAChRs seem to be largely involved in the presynaptic actions of $\mathrm{A} \beta$ at picomolar concentration, the results indicate that the action of $\mathrm{A} \beta$ when present at high nanomolar concentration on presynaptic $\mathrm{Ca}^{2+}$ may be largely at non- $\alpha 7$-containing nAChRs, owing to a more pronounced sensitivity of the responses to the nicotinic antagonist dihydro- $\beta$-erythroidine. The results demonstrating that relatively high concentration of $\mathrm{A} \beta$ can overcome the occlusion by nicotine of the action of picomolar levels of $\mathrm{A} \beta$ are, in contrast, not inconsistent with the possibility that $\mathrm{A} \beta$ may be activating a pathway in the nerve endings that is independent of nAChRs. Other indications of direct stimulatory effects of $\mathrm{A} \beta$ that are most likely independent of nicotinic receptors have also been noted. For example, $\mathrm{A} \beta$ peptide was found to evoke a nonselective inward ion current in rat cortical neurons (Furukawa et al., 1994). The $\mathrm{A} \beta$ peptide-induced current was proposed to have resulted from the formation of cation channels, reported previously, wherein $\mathrm{A} \beta$ was used at particularly elevated concentrations (micromolar) (Lin et al., 2001). Here, however, $A \beta$ induced increases in presynaptic $\mathrm{Ca}^{2+}$ in a reversible manner that was insensitive to $\mathrm{Zn}^{2+}$, ruling out formation of channels.

An important question is whether $\mathrm{A} \beta$ induced alterations in presynaptic $\mathrm{Ca}^{2+}$ affect the release of neurotransmitter. In one study, $A \beta$ was actually found to have an inhibitory effect on $\mathrm{K}^{+}$-evoked acetylcholine release from hippocampal slices (Kar et al., 1996, 1998), although the time frame of these measurements was rather extended. In view of the sustained increases in presynaptic $\mathrm{Ca}^{2+}$ in response to $\mathrm{A} \beta$ that were observed here, it may be that neurotransmitter release evoked subsequent to $A \beta$ treatment would be inhibited perhaps as a consequence of a longer-term depressive and/or toxic effect on the nerve terminal. In contrast, it would be predicted that neurotransmitter release would be initially evoked by $\mathrm{A} \beta$ as a result of the increased presynaptic $\mathrm{Ca}^{2+}$. Previous observations of an inhibitory effect of $\mathrm{A} \beta$ peptide on nicotine-stimulated increases in spontaneous neurotransmitter release in cultured hippocampal neurons did not, however, note a direct effect of $\mathrm{A} \beta$ alone (Liu et al., 2001). Effects, or lack thereof, of $\mathrm{A} \beta$ on exocytosis in individual nerve terminals from brain would require imaging using, for example, amphipathic fluorescent dyes such as FM1-43 (Rondé and Nichols, 1998).

Another issue is whether sustained presynaptic $\mathrm{Ca}^{2+}$ in response to $\mathrm{A} \beta$ will activate certain intracellular signaling pathways, such as protein kinases. Previous observations using hippocampal slices demonstrated extracellular signal-regulated kinase (ERK) activation in response to $\mathrm{A} \beta$ (Dineley et al., 2001). Whether $\mathrm{A} \beta$ activates protein kinase pathways, such as ERK, in the presynaptic nerve terminal is currently under investigation.

Despite several lines of evidence, including our own, indicating the possibility of a direct interaction between $\mathrm{A} \beta$ and nAChRs, such an interaction remains to be proven. It remains possible that $A \beta$ interacts with a protein that associates with 

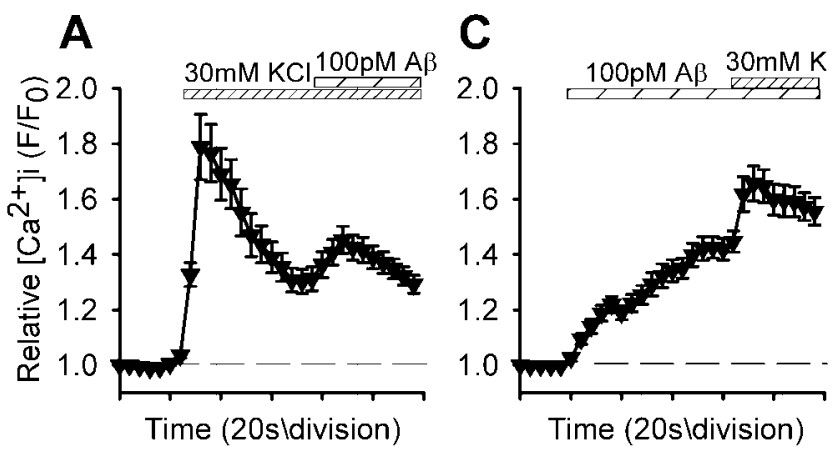

B

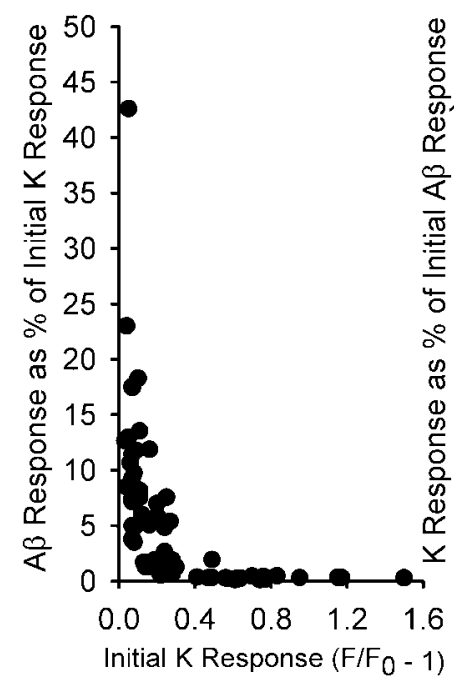

D

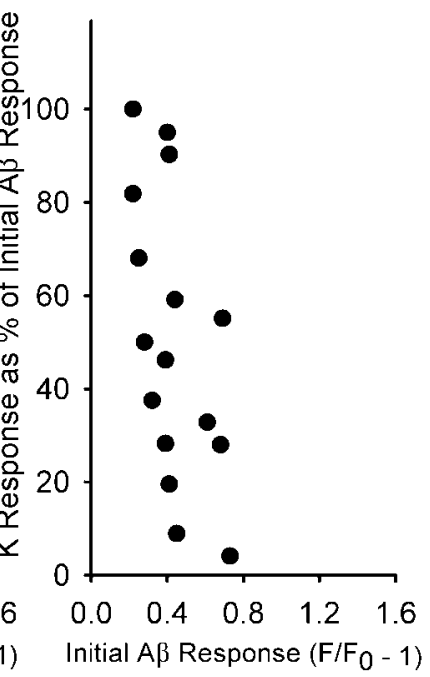

Figure 7. $\mathrm{Ca}^{2+}$ responses in isolated hippocampal nerve endings to $A \beta$ after prior depolarization by $\mathrm{KCl}$ compared with $\mathrm{Ca}^{2+}$ responses to depolarization by $\mathrm{KCl}$ after $\mathrm{A} \beta$. The averaged responses in $A(n=26)$ and $C(n=18)$ are means \pm SEM. Individual peak responses to the second agent in $B(n=71)$ and $D(n=16)$ are correlated to the initial peak responses of the first agent, with each response to the second agent normalized to the response to the first agent as a percentage.

nAChRs and perhaps other signaling molecules. In contrast, nicotinic antagonists were able to inhibit $\mathrm{A} \beta$-evoked presynaptic $\mathrm{Ca}^{2+}$ increases, indicating, as noted previously, some overlap of $\mathrm{A} \beta$ interaction with the ligand binding site(s). Sorting out the actual presynaptic targets for $\mathrm{A} \beta$ will entail a series of detailed molecular studies using, for example, preparations containing $\mathrm{nAChRs}$ modified by site-directed mutagenesis, especially in view of differences noted in the structural components of $\mathrm{nAChRs}$ that are essential for agonist binding as compared with antagonist binding (Arias, 1997).

Although speculative at present, our results might suggest that as $\mathrm{A} \beta$ begins to accumulate near synaptic sites, nicotinemediated presynaptic regulation will be initially disrupted, although in a manner dependent on nerve activity-coupled presynaptic $\mathrm{Ca}^{2+}$ changes. Nicotinic receptors, particularly presynaptic nAChRs, have been implicated in long-term potentiation in the hippocampus (Fujii et al., 1999; Matsuyama et al., 2000) as well as the ventral tegmental area (Mansvelder and McGehee, 2000), and, thus, $\mathrm{A} \beta$ disruption of signaling via these receptors could have consequences for cognitive function. As $\mathrm{A} \beta$ further accumulates, toxic effects on nerve terminals may arise. For example, prolonged $\mathrm{A} \beta$ has been shown to alter nerve terminal mitochondrial function (Mattson et al., 1998). A key question is to what extent such toxicity might be a consequence of sustained presyn- aptic $\mathrm{Ca}^{2+}$ as compared with $\mathrm{A} \beta$ gaining entry into the nerve terminal (Kienlen-Campard et al., 2002; Nagele et al., 2002). It is likely that disruption of neuronal function at multiple levels via several pathways ultimately underlies the pathology arising over the course of Alzheimer's disease.

\section{References}

Arias HR (1997) Topology of ligand binding sites on the nicotinic acetylcholine receptor. Brain Res Rev 25:133-191.

Auld DS, Kar S, Quirion R (1998) $\beta$-Amyloid peptides as direct cholinergic neuromodulators: a missing link? Trends Neurosci 21:43-49.

Brendza RP, O'Brien C, Simmons K, McKeel DW, Bales KR, Paul SM, Olney JW, Sanes JR, Holtzman DM (2003) PDAPP; YFP double transgenic mice: a tool to study amyloid- associated changes in axonal, dendritic, and synaptic structures. J Comp Neurol 456:375-383.

Clarke PB, Reuben M (1996) Release of $\left[{ }^{3} \mathrm{H}\right]$-noradrenaline from rat hippocampal synaptosomes by nicotine: mediation by different nicotinic receptor subtypes from striatal $\left[{ }^{3} \mathrm{H}\right]$-dopamine release. $\mathrm{Br} \mathrm{J}$ Pharmacol 117:595-606.

Coggan JS, Paysan J, Conroy WG, Berg DK (1997) Direct recording of nicotinic responses in presynaptic nerve terminals. J Neurosci 17:5798-5806.

Díaz-Hernández M, Pintor J, Castro E, Miras-Portugal MT (2002) Colocalisation of functional nicotinic and ionotropic nucleotide receptors in isolated cholinergic synaptic terminals. Neuropharmacology 42:20-33.

Dineley KT, Westerman M, Bui D, Bell K, Hsiao Ashe K, Sweatt JD (2001) $\beta$-Amyloid activates the mitogen-activated protein kinase cascade via hippocampal $\alpha 7$ nicotinic acetylcholine receptors: in vitro and in vivo mechanisms related to Alzheimer's disease. J Neurosci 21:4125-4133.

Dineley KT, Bell KA, Bui D, Sweatt JD (2002) $\beta$-Amyloid peptide activates $\alpha 7$ nicotinic acetylcholine receptors expressed in Xenopus oocytes. J Biol Chem 277:25056-25061.

Dunkley PR, Jarvie PE, Heath JW, Kidd GJ, Rostas JAP (1986) A rapid method for isolation of synaptosomes on Percoll gradients. Brain Res 372:115-129.

El Khoury J, Hickman SE, Thomas CA, Loike JD, Silverstein SC (1998) Microglia, scavenger receptors, and the pathogenesis of Alzheimer's disease. Neurobiol Aging 19:S81-S84.

Fabian-Fine R, Skehel P, Errington ML, Davies HA, Sher E, Stewart MG, Fine A (2001) Ultrastructural distribution of the $\alpha 7$ nicotinic acetylcholine receptor subunit in rat hippocampus. J Neurosci 21:7993-8003.

Fujii S, Ji Z, Morita N, Sumikawa K (1999) Acute and chronic nicotine exposure differentially facilitate the induction of LTP. Brain Res 846:137-143.

Furukawa K, Abe Y, Akaike N (1994) Amyloid $\beta$ protein-induced irreversible current in rat cortical neurones. NeuroReport 5:2016-2018.

Garzon-Rodriguez W, Sepulveda-Becerra M, Milton S, Glabe CG (1997) Soluble amyloid $\mathrm{A} \beta(1-40)$ exists as a stable dimer at low concentrations. J Biol Chem 272:21037-21044.

Gravina SA, Ho L, Eckman CB, Long KE, Otvos Jr L, Younkin LH, Suzuki N, Younkin SG (1995) Amyloid $\beta$ protein $(\mathrm{A} \beta)$ in Alzheimer's disease brain. Biochemical and immunocytochemical analysis with antibodies specific for forms ending at $\mathrm{A} \beta 40$ or $\mathrm{A} \beta$ 42(43). J Biol Chem 270:7013-7016

Gray R, Rajan AS, Radcliffe KA, Yakehiro M, Dani JA (1996) Hippocampal synaptic transmission enhanced by low concentrations of nicotine. $\mathrm{Na}-$ ture 383:713-716.

Huang TH, Yang DS, Plaskos NP, Go S, Yip CM, Fraser PE, Chakrabartty A (2000) Structural studies of soluble oligomers of the Alzheimer $\beta$-amyloid peptide. J Mol Biol 297:73-87.

Irizarry MC, McNamara M, Fedorchak K, Hsiao K, Hyman BT (1997) APPSw transgenic mice develop age-related $\mathrm{A} \beta$ deposits and neuropil abnormalities, but no neuronal loss in CA1. J Neuropathol Exp Neurol 56:965-973.

Iwatsubo T, Odaka A, Suzuki N, Mizusawa H, Nukina N, Ihara Y (1994) Visualization of $A \beta 42(43)$ and $A \beta 40$ in senile plaques with end-specific $\mathrm{A} \beta$ monoclonals: evidence that an initially deposited species is $\mathrm{A} \beta 42(43)$. Neuron 13:45-53.

Kar S, Seto D, Gaudreau P, Quirion R (1996) $\beta$-Amyloid-related peptides inhibit potassium-evoked acetylcholine release from rat hippocampal slices. J Neurosci 16:1034-1040.

Kar S, Issa AM, Seto D, Auld DS, Collier B, Quirion R (1998) Amyloid 
$\beta$-peptide inhibits high-affinity choline uptake and acetylcholine release in rat hippocampal slices. J Neurochem 70:2179-2187.

Kienlen-Campard P, Miolet S, Tasiaux B, Octave JN (2002) Intracellular amyloid- $\beta 1-42$, but not extracellular soluble amyloid- $\beta$ peptides, induces neuronal apoptosis. J Biol Chem 277:15661-15670.

Kiyosawa A, Katsurabayashi S, Akaike N, Pang ZP, Akaike N (2001) Nicotine facilitates glycine release in the rat spinal dorsal horn. J Physiol (Lond) 536:101-110.

Klein WL, Krafft GA, Finch CE (2001) Targeting small A $\beta$ oligomers: the solution to an Alzheimer's disease conundrum? Trends Neurosci 24:219-224.

Kotilinek LA, Bacskai B, Westerman M, Kawarabayashi T, Younkin L, Hyman BT, Younkin S, Ashe KH (2002) Reversible memory loss in a mouse transgenic model of Alzheimer's disease. J Neurosci 22:6331-6335.

Kulak JM, McIntosh JM, Yoshikami D, Olivera BM (2001) Nicotine-evoked transmitter release from synaptosomes: functional association of specific presynaptic acetylcholine receptors and voltage-gated calcium channels. J Neurochem 77:1581-1589.

Lambert MP, Barlow AK, Chromy BA, Edwards C, Freed R, Liosatos M, Morgan TE, Rozovsky I, Trommer B, Viola KL, Wals P, Zhang C, Finch CE, Krafft GA, Klein WL (1998) Diffusible, nonfibrillar ligands derived from $\mathrm{A} \beta_{1-42}$ are potent central nervous system neurotoxins. Proc Natl Acad Sci USA 95:6448-6453.

Léna C, Changeux J-P (1997) Role of $\mathrm{Ca}^{2+}$ ions in nicotinic facilitation of GABA release in mouse thalamus. J Neurosci 17:576-585.

Lin H, Bhatia R, Lal R (2001) Amyloid $\beta$ protein forms ion channels: implications for Alzheimer's disease pathophysiology. FASEB J 15:2433-2444.

Liu Q-S, Kawai H, Berg DK (2001) $\beta$-Amyloid peptide blocks the response of $\alpha 7$-containing nicotinic receptors on hippocampal neurons. Proc Natl Acad Sci USA 98:4734-4739.

Lorenzo A, Yankner BA (1994) $\beta$-Amyloid neurotoxicity requires fibril formation and is inhibited by Congo red. Proc Natl Acad Sci USA 91: 12, 24312:247.

Lue L-F, Kuo Y-M, Roher AE, Brachova L, Shen Y, Sue L, Beach T, Kurth JH, Rydel RE, Rogers J (1999) Soluble amyloid $\beta$ peptide concentration as a predictor of synaptic change in Alzheimer's disease. Am J Pathol 155:853-862.

Lue L-F, Walker DG, Brachova L, Beach TG, Rogers J, Schmidt AM, Stern DM, Yan SD (2001) Involvement of microglial receptor for advanced glycation endproducts (RAGE) in Alzheimer's disease: identification of a cellular activation mechanism. Exp Neurol 171:29-45.

Mansvelder HD, McGehee DS (2000) Long-term potentiation of excitatory inputs to brain reward areas by nicotine. Neuron 27:349-357.

Marchi M, Risso F, Viola C, Cavazzani P, Raiteri M (2002) Direct evidence that release-stimulating $\alpha 7^{\star}$ nicotinic cholinergic receptors are localized on human and rat brain glutamatergic axon terminals. J Neurochem 80:1071-1078.

Matsuyama S, Matsumoto A, Enomoto T, Nishizaki T (2000) Activation of nicotinic acetylcholine receptors induces long-term potentiation in vivo in the intact mouse dentate gyrus. Eur J Neurosci 12:3741-3747.

Mattson MP, Partin J, Begley JG (1998) Amyloid $\beta$-peptide induces apoptosis-related events in synapses and dendrites. Brain Res 807:167-176.

McGehee DS, Heath MJS, Gelber S, Devay P, Role LW (1995) Nicotine en- hancement of fast excitatory synaptic transmission in CNS by presynaptic receptors. Science 269:1692-1696.

McLean CA, Cherny RA, Fraser FW, Fuller SJ, Smith MJ, Beyreuther K, Bush AI, Masters CL (1999) Soluble pool of A $\beta$ amyloid as a determinant of severity of neurodegeneration in Alzheimer's disease. Ann Neurol 46:860-866.

Nagele RG, D'Andrea MR, Anderson WJ, Wang H-Y (2002) Intracellular

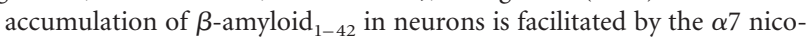
tinic acetylcholine receptor in Alzheimer's disease. Neuroscience 110:199-211.

Nayak SV, Rondé P, Spier AD, Lummis SCR, Nichols RA (2000) Nicotinic receptors co-localize with $5-\mathrm{HT}_{3}$ serotonin receptors on striatal nerve terminals. Neuropharmacology 39:2681-2690.

Nayak SV, Dougherty JJ, McIntosh JM, Nichols RA (2001) $\mathrm{Ca}^{2+}$ changes induced by different presynaptic nicotinic receptors in separate populations of individual striatal nerve terminals. J Neurochem 76:1860-1870.

Nichols RA, Mollard P (1996) Direct observation of 5- $\mathrm{HT}_{3}$ receptorinduced increases in calcium levels in individual brain nerve terminals. J Neurochem 67:581-592.

Pettit DL, Shao Z, Yakel J (2001) $\beta$-Amyloid - $_{1-42}$ peptide directly modulates nicotinic receptors in the rat hippocampal slice. J Neurosci 21:RC120.

Radcliffe KA, Fisher JL, Gray R, Dani JA (1999) Nicotinic modulation of glutamate and GABA synaptic transmission of hippocampal neurons. Ann NY Acad Sci 868:591-610.

Rondé P, Nichols RA (1998) High calcium permeability of serotonin 5- $\mathrm{HT}_{3}$ receptors on presynaptic nerve terminals from rat striatum. J Neurochem 70:1094-1103.

Rondé P, Nichols RA (2001) Postsynaptic target regulates functional responses induced by $5-\mathrm{HT}_{3}$ serotonin receptors on axonal varicosities of NG108-15 hybrid neuroblastomal cells. Neuroscience 102:979-987.

Selkoe DJ (1998) The cell biology of $\beta$-amyloid precursor protein and presenilin in Alzheimer's disease. Trends Cell Biol 8:447-453.

Sze CI, Troncoso JC, Kawas C, Mouton P, Price DL, Martin LJ (1997) Loss of the presynaptic vesicle protein synaptophysin in hippocampus correlates with cognitive decline and Alzheimer disease. J Neuropathol Exp Neurol 56:933-944.

Teplow DB (1998) Structural and kinetic features of amyloid $\beta$-protein fibrillogenesis. Amyloid Int J Exp Clin Invest 5:121-142.

Terry RD, Masliah E, Salmon DP, Butters N, DeTeresa R, Hill R, Hansen LA, Katzman R (1991) Physical basis of cognitive alterations in Alzheimer's disease: synapse loss is the major correlate of cognitive impairment. Ann Neurol 30:572-580.

Walter J, Kaether C, Steiner H, Haass C (2001) The cell biology of Alzheimer's disease: uncovering the secrets of secretases. Curr Opin Neurobiol 11:585-590.

Wang H-Y, Lee DHS, Davis CB, Shank RP (2000a) Amyloid peptide A $\beta_{1-42}$ binds selectively and with picomolar affinity to $\alpha 7$ nicotinic acetylcholine receptors. J Neurochem 75:1155-1161.

Wang H-Y, Lee DHS, D'Andrea MR, Peterson PA, Shank RP, Reitz AB (2000b) $\beta$-Amyloid - $_{1-42}$ binds to $\alpha 7$ nicotinic acetylcholie receptor with high affinity. J Biol Chem 275:5626-5632.

Westerman M, Cooper-Blacketer D, Mariash A, Kotilinek L, Kawarabayashi T, Younkin LH, Carlson G, Younkin S, Ashe KH (2002) The relationship between $A \beta$ and memory in the Tg2576 mouse model of Alzheimer's disease. J Neurosci 22:1858-1867. 